\title{
Undeclared Social Bracketing Of Ex-Soldiers: A Potential Bottleneck for Their Successful Transition
}

\author{
Rajesh Verma $^{1 *}$
}

\section{ABSTRACT}

The ex-soldier, henceforth will be referred as ex throughout this paper, is someone who had retired from active defence service with pension from defence fund. The purpose of the study is to explore and explain the imperceptible humiliation (Undeclared Social Bracketing) ex-soldiers face in the course of their transition period and after that. The complex social set-up of the Indian civilization is passing through a technology modulated collective revolution; soldier cannot remain aloof. The soldier when in active service enjoy the highest regard in the society, but once he hangs up his uniform, he faces awkward situation. It is not easy for him to re-assimilate with the society which he left long ago. The transition from military life to civilian life is tricky issue for him. Surprisingly, the issue is not yet considered worthy of studying. I tried to highlight the finer points of the predicament the ex faces in the second innings of his life. Various rehabilitation and resettlement policies run by state as well as central governments too are on back foot at this front. The cause behind the situation is the goody-goody mindset and judgmental attitude of the members of the society. The author also tried to suggest some from the horse's mouth simple solutions. However, constructive suggestions, views, reviews on the subject are warmly solicited.

Keywords: Ex-soldier (ex), Social Bracketing, Imperceptible, Transition, Judgmental, Military life.

\section{Rationale for choosing this topic}

There are several reasons for choosing this topic few of them are appended below:

1. This topic is closely related to my doctorate topic i.e. "General wellbeing, adjustment and achievements in civil life vis-à-vis personal resources and demands of non-commissioned officers of army ex-servicemen".

2. To create awareness and sensitizes the general populace and policy makers regarding the issue.

\footnotetext{
${ }^{1}$ Research Scholar, MD University, Rohtak, India

*Responding Author

(C) 2016 I R Verma; licensee IJIP. This is an Open Access Research distributed under the terms of the Creative Commons Attribution License (http://creativecommons.org/licenses/by/2.0), which permits unrestricted use, distribution, and reproduction in any Medium, provided the original work is properly cited.
} 
3. This is a conceptual paper highlighting the discriminatory stigma these erstwhile soldiers have to face from the very persons whom once they protected.

4. Ex soldiers have little voice in saying because they are considered as dead vote bank by politicians. It is a small yet significant attempt to take up issue so that it reaches to highest level.

5. Being an honest and disciplined lot these soldiers find it difficult to cope up with tits and bits of civil society,

6. The intellectuals \& academicians need to be made aware of their plight because through this platform only who's who of society emerges.

\section{INTRODUCTION}

The profession of soldier is older than oldest scripture, culture and any other written record available on earth. Soldier, the social protagonist always remained a idolized entity for the adrenaline brimmed youth, a fascinating savior in the tales for the kids, an endless wait for the newlywed damsel, focal point of folklores, protector of freedom, all weather rescuer and of course a perfect bridegroom ${ }^{2}$. The word soldier is derived from English word 'soudeour', meaning mercenary, from 'soudee', meaning shilling's worth or wage. The word is also related to the Medieval Latin 'soldarius', meaning soldier (literally, "one having pay"). The earliest known written reference to the role of soldier in India can be found in oldest scriptures i.e. Vedas. Even before the advent of agricultural practices took root in the Indus River Valley, one of the world's earliest urban civilizations (circa, 3300 BC) the soldier was most important component of the travelling tribes. Around $1000-500$ BC, two ancient Indian epics were written, the Ramayana and the Mahabharata. Both epics are centered on the wars and conflicts between the various kingdoms and various tribes (ancientmilitary.com). The soldier used to be fundamental, intelligent fighting machine that decided the fate of ancient kingdoms. The settled agricultural practices demanded an organized pool of soldiers to protect their produce from uncalled-for human and animal invaders. Human history is incomplete without the mention of role of a soldier. The soldier remained one of the most potent modules of sustaining peace in real as well as perceived terms of the society till date. This unit of society provided psychological as well as physical sense of supremacy with inflated confidence. The mere physical presence of a soldier is known to infuse a positive push to the internal motivational element. The erstwhile soldier was unparallel protagonist for the contemporary society worthy of emulating. The rousing community welcome one use to get on returning is the thing of the past now-a-days, courtesy the ugly hood of unabated consumerism coupled with declining value system of the society. The same central character when hangs up uniform, simultaneously loosing the patina of glorious active service, is re-christened as Ex-serviceman or Ex-soldier. The same bunch of people who waited anxiously for his arrival on leave, offered bear hugs, showered praises on him, carefully

\footnotetext{
${ }^{2}$ In olden days the principal selection criterion for the potential bridegroom was physical deformity free body. And soldier was an epitome of physical fitness because it is well known fact that selection in defense services is the best certificate of the trait. Now, the selection paradigm has gone sea change.
} 


\section{Undeclared Social Bracketing Of Ex-Soldiers: A Potential Bottleneck for Their Successful Transition}

listened from him interesting anecdotes, company him in lively get-togethers etc. reverse their role as and when he retires and engage in Undeclared Socially Bracketing him.

\section{Objectives}

1. To explore and explain the imperceptible humiliation (Undeclared Social Bracketing) exsoldiers face in their transition.

2. To look at all possible austere solutions to the predicament of the ex.

\section{'How' and 'What' of Social Bracketing}

Social profiling or bracketing a term particularly reserved for the companies collecting, accumulating and analyzing online data in respect of a probable employee. These companies, by various advanced technological tools, collect online data about their customers and prospects and transform that data into sophisticated, social profiles that give them insight into both current and future behavior (Dominic Basulto, 2012). It has been argued by advocates of social bracketing that it strengthens predictive modeling and empowers text analytics by providing user based context which is handy in tailored products, higher customer satisfaction-cum-retention etc. However, social bracketing in respect of ex-soldiers is not a so sweet pudding rather a grey shade. It's not a new phenomenon but as old as soldier as profession. Social bracketing of exsoldiers in a negative shade is a pan-India affair. The aggregate of derogatory behavioural outcomes such as calling names, linking present activities with the past, isolating on community occasions, disregarding socially productive-cum-assenting behaviour as hangover of the past, is roughly termed as social bracketing. Name calling tends to resonate in the mind of the victim for very long period. A type of discriminatory behaviour for which the gullible - in context of changed social milieu - 'ex' pays the price in terms of faulty adjustment. They are being treated [rather maltreated] differently because of their past profession, perhaps only profession having opposite social connotations while in service and out of service. The out-of-service half mind fellow while in-service enjoyed considerable social regard which has now metamorphosed into an exclusive class unto themselves. This lot (ex-soldiers) who exhausted their golden years of life separated from their loved ones in wild ravines, treacherous mountains, scorching desert sun, bone chilling sub-zero temperatures, extremely humid and leaches infected roller blind forests, deadly sludgy terrain while under constant threat of being hit by burst of dreaded gunshots needs to be made comfortable, counseled, re-skilled and refitted in the system that has gone sea change since they left, so that they can adjust to the environment while simultaneously fruitfully enjoy the twilight years of their life. This will be a great service to the veterans who served with passion and without any fuss. The flip side, of course, is that they face incalculable loss to their internal motivational component which further alienates them from successful re-bonding. Social bracketing denies access to intricate affairs of the complicated social apparatus. It results in collateral failure on the part of the actor to understand the subtle functioning of the system. Interpolation of past with present by secondary variables is a psychological barrier ensuing stretched painful experiences. By certain estimates more than 93\% ex faced some or other type of humiliating situations during their adjusting phase and even later. The fear of stigmatization by 
way of social profiling forces the ex to withhold the information about his past profession. Evidently, entry into a random system from well laid out controlled and predictable system where behavioural events are easy to envisage, demands intense and immediate re-negotiation of whole cognitive configuration. Not a cake walk. For to achieve a successful transition all concerned components need to collaborate in a synergized fashion deeming $e x$ as the focal point. The ex faces bumpy paradox such as, if he behaves according to contemporary social paradigms; he behaved so because he is a fauji and if he behaves otherwise he is a fauji with brain in the knees (a brainless fellow). If he attends a social event with punctuality he is a fauji and if he adapts to civil system (joining an event from 2 to 4 hrs behind schedule time) he will again be fauji. He has to tread a thin line of multifaceted social system where he is deemed a well mannered extra ordinary useful fellow unless his past is discovered. The moment, his past is unpacked his colleagues' perceptual outcome is significantly changed. Suddenly, the strong interpersonal behavioural relations vis-à-vis ex takes u-turn. The phenomenon called role reversal dominates the behavioural landscape. Interestingly, on account of the availability of inconsequential bit of information, the total behavioural environment changes drastically.

Every action of his is watched carefully, his dressing style is a evergreen topic of debate, what caller tone his mobile sing, the type and colour of his shoes, the way he drives, the type of food he eats, the language he speaks, the books he reads, the places he visits, the way he shops, the way he treat street baggers etc. If he brushes his teeth twice a day, he is half minded. If he uses spoon he is alien. If he switches off not-in-use electric/electronic appliances he deserves to be resend. If he advices children he is old rut who need to be avoided at all times. If he rightfully and judiciously bargains he is miserable as well as careless and selfish fellow without any regard for the poor vendor. It is another matter that the vendor owns sparkling SUV with heavy golden chain around his neck.

Drinks and non-vegetarian food are regarded as social hallmark of the ex. If you are an ex you must be certainly in possession of a stuff called $X X X$ RUM and Scotch, an approach of the general populace. You will be mollycoddled till you greet your guests (including strangers) with glasses full. A seldom polite ' $N O$ ' means you must be fully prepared to accept so many unusual names coupled with flight of so many erstwhile [supposed] friends. Incidentally, the ex mostly suffers unwanted episodes engendered by the close circuit friends and family members. It's an upsetting experience.

The complete philosophy of undeclared social bracketing is a reprehensible act. It's a myopic interpersonal behaviour. Person or profession specific social bracketing is malevolence for the growth of society in general and specifically for the gullible $e x$. The transition demands constant conscious behaviour which in fact, is a self struggle in context of social archetypes. Regardless of well thought resettlement/rehabilitation system run by the centre as well state governments, the $e x$ faces social stigma of being profiled for long time. 


\section{Undeclared Social Bracketing, 'Why'?}

The incidences of social bracketing of ex in our part of land are cause of social concern. It's an uncared for but have wide spread occurrence where ex bears in silence. The phenomena of undeclared social bracketing trace its roots in the human quest for exclusive dominance. In order to prevail over the arguments we human beings destined to dent the opponent's self-esteem to gain immediate and observable hand. A tiny verbal whack on opponents' self-esteem is sufficient enough to unsettle the nerves ${ }^{3}$. The ulterior motive is to disrupt the sequence of well developed thought process. Disruption causes covert imbalance in the individual's flow of logical verbal outbursts. Owing to stealthy imbalance, brain tends to lose the track. Finally, it results in derailing the emotional control. Emotional control is the function of individual's emotional intelligence. Individuals with high emotional intelligence are found to resist the disruptive design while individuals with average or low emotional intelligence fall short of the trial. Evidence suggests that soldiers have hardened emotional stability in respect of professionalism while fragile emotional set up vis-à-vis social set up. The later part of emotional set up interferes most with their transition making it tougher than toughest mission ever undertaken. Meanwhile, human beings tend to, suit their convenience, modulate the argumentative language or venerate it with conjured-up facts and figures. The prospective failure to prevail over the issue prod humans to use phrases as well as sentences which tend to hit [hurt] the core of self. The central desire of sailing over the arguments in order to preserve the 'self' rather 'false ego' intact and demean the contender results in undeclared social bracketing. It is a kind of psychological ghettoism. The ex suffers this undeclared social bracketing owing to his social upbringing in a unique set up. The thinking style, perception and stance get transformed into nuance of perfection according to the requirements of training. In consequent of undeclared social bracketing ex is most likely to face community stigma. Stigma generally denotes the possession of a trait that marks one out as different from others and is negatively regarded and is often a precursor to discrimination or unfair treatment (Green Gill et. al. 2008). As well as stigma from others, those requiring help will also stigmatize themselves as they are aware of the attitudes of their peers and share the cultural values that equate emotional stress with weakness (Greene-Shortridge, Britt \& Castro 2007). This process of self-stigmatization is strongly associated with low self-esteem. Low selfesteem is known to engender social alienation which is a type of escapism. The changed economic settings too has played spoilsport in the process. The idea of consumerism ${ }^{4}$, advent of new battle technology, real time war coverage, changed role of soldier, terrorism, and expansion of avenues of employment also has categorically contributed in the strengthening of the ugly process. It's no denying fact that somewhere few dirty black sheep among the soldiers played significant role in furthering the issue.

\footnotetext{
${ }^{3}$ Remember Zinadine Zidane episode

${ }^{4}$ Consumerism took a great toll on chances of marriage for the soldiers especially Army personal. In various unfortunate cases the bride groom has been rejected owing to his belongingness from the Army. A regrettable role reversal.
} 


\section{Some Suggested Ways and Means to Tackle the Issue (Nuisance)}

The Indian social set up is complex sub-division of great Indian dynamic civilization. And soldier is an integral part of it. The face value of soldier in respect to society too has undergone enormous change. Owing to the transformation in face value, the soldier is fast losing its erstwhile societal sheen. This is resulting in psychological ghettoism. An urgent need is being felt to offset the issue so that no ex ever feels humiliated or demeaned. The psychological battle can be fought with the active involvement of intellectual section of the society. The following non-demanding yet simple demeanor is expected from the [doyens of] society.

(i) Unconditional acceptance.

(ii) Appreciative behaviour rather than judgmental behaviour.

(iii) Give time for comprehending the complex issues of the society or let them settle down before raising your expectations.

(iv) Delinking [Intelligently] of past professional behaviour with the present one.

(v) Perceptual as well as mind-set adjustment.

(vi) Diversified-cum-accommodative social stance.

(vii) Positive implementation of government sponsored rehabilitation and resettlement policies i.e. action oriented approach.

(viii) Extensive scientific research on the life and behavioural style of $e x$.

(ix) Aggressive but constructive portraying through the entertainment industry.

(x) Affirmative discourage of humiliating behaviour.

(xi) Finally, 'Please' understand that they too are fellow humans and sliver of same subdivision of which you belong.

\section{In a Nutshell}

A society can be judged by the way it treats its ex and serving soldiers ${ }^{5}$. The society must not to turn blind eye to the prospective undeclared threat. A highly skilled human work force when seek to adjust with the new social formation, it is the sole responsibility of the society to embrace these work force with grace. The $e x$ is a highly emotional being with subtle understanding of social framework. Undeclared social bracketing tends to alter the fledgling perceptual phenomenon of the new (ex) entrants. The society needs to manifest subterranean faith in the adaptability of the ex. Sometimes it is possible that $e x$ behaves in a certain way that may not be compatible with the style of the society. It is also possible that sometimes the ex may use fused language not spoken in the particular area. Or it is also possible that the ex works in a manner not suited locally though fruitful. Along with there may be many other possibilities where $e x$ is found to be not in synchronous with existing environment. It does not signify that he should be humiliated on these petty issues. Accommodative and non-judgmental behaviour coupled with mutual trustworthiness can be instrumental in combating the last frontier so that transition can be on happy note and the ex can peacefully enjoy the twilight years of his life.

\footnotetext{
${ }^{5}$ A slight alteration of Mahatma Gandhi’s maxim, "A civilization can be judged by the way it treats its minorities".
} 


\section{Significance (Importance)}

1. There is a plethora of research work available on ex defence Officers who face relatively little or no discrimination owing to their high SES, whereas almost nil research work is available on Ex-servicemen (non-commissioned ranks).

2. Most of the studies regarding the topic are undertaken in western part of world or American continent which has little relevance in our cultural context. Moreover, the western people have encouraging behaviour vis-a-vis ex soldiers are concerned. In our part, yes, we respect ex but for the sake of public approval or some personal gains (already mentioned in the paper).

3. Society must not engage in discriminatory behaviour, instead offer much needed emotional \& intellectual support to them so that transition from military life to civilian can be smooth.

4. To ensure that civilians should not discriminate someone on the basis of his/her profession.

5. The ex soldiers must not be viewed through the prism of canteen and bottles.

\section{REFERENCES}

Basulto, Dominic. (2012). Is social profiling discrimination?. Washington Post. March, 05.

Economic Times Bureau. (2012). From teachers to IAS officers to ex-servicemen, India Inc now hires them all. The Economic Times, Nov 16, 2012.

Gill, Green., Dan, O’Neill., \& Steven Walker. (2008). Welfare and warfare an uneasy mix: personal experiences of and organizational responses to emotional and mental health issues in young ex-service personnel. University of Essex, Wivenhoe Park, Colchester. CO4 3SQ.

Greene-Shortridge, T.M., Britt, T.W., \& Castro, C.A. (2007). The stigma of mental health problems in the military. Military Medicine, 172(2), p.157-61.

Government of India Information. (1991). Ministry of Health and Family Welfare. Nirman Bhawan; New Delhi: 1991. p. 32, 55.

Kishore, Satyendra. (1991). Re-settlement of Ex-servicemen in India: Problems, Patterns and Prospects.New Delhi: Concept publishing company.

Kumbhar, S. K., Joshi. J. K., Tapare, V. S., \& Yadav, J. U. (2007). Morbidity profile of exservicemen residing in Sangli-Miraj-Kupwad municipal corporation area and its relationship with certain clinico-epidemiological factors. Indian Journal of Community Med;32:111-4.Retrievedon Oct, 6, 2014 from www.wikipedia.org/wiki/Soldier.Retrieved on Oct, 6, 2014 from http://www.ancientmilitary.com/ancient-india-military.htm

DOP\&T office Memo No.36034/1/2006-Estt (Res) dated 04 Oct 2012 and this order came into force from the date it is published in the Gazette of India vide G.S.R 757(E) dated 10th Oct 2012. 